\title{
CLONAGEM E EXPRESSÃO HETERÓLOGA DE UMA MANGANÊS PEROXIDASE DE Trametes villosa (Sw.) Kreisel, A PARTIR DE CÉLULAS DE Escherichia coli.
}

\author{
Cleidineia Souza de Santana ${ }^{1}$; Raquel Guimarães Benevides ${ }^{2}$; Dalila de Souza \\ Santos Ferreira ${ }^{3}$ e Aristóteles Góes Neto ${ }^{4}$ \\ 1. Bolsista PIBIC/CNPq, Graduando em Bacharelado em Ciências Biológicas, Universidade Estadual de Feira de \\ Santana, e-mail: s.santanacleide@yahoo.com.br \\ 2. Orientador, Departamento de Ciências Biológicas, Universidade Estadual de Feira de Santana, e-mail: \\ raquelgb@gmail.com \\ 3. Participante do projeto, Departamento de Ciências Biológicas, Universidade Estadual de Feira de Santana, e-mail: \\ dalilassouza@gmail.com \\ 4. Participante do projeto, Departamento de Microbiologia, Universidade Federal de Minas Gerais, e-mail: \\ arigoesneto@gmail.com
}

PALAVRAS-CHAVE: basidiomiceto, enzima recombinante, lignina

\section{INTRODUÇÃO}

A indústria de açúcar e etanol tem um importante papel no processo de desenvolvimento do Brasil, assim há a geração de uma quantidade elevada de resíduos agroindustriais. As matérias-primas lignocelulósicas são as fontes renováveis mais abundantemente encontradas na natureza, sendo compreendidas, pelos resíduos agroindustriais, pelos resíduos urbanos e madeiras. Dentre essas, os resíduos agroindustriais ganham destaque por serem derivados do processamento de matérias primas com maior valor agregado (CASTRO E PEREIRA JR., 2010).

Os fungos são um dos mais importantes decompositores na cadeia alimentar sendo capazes de degradar de forma eficiente uma vasta quantidade de resíduos. A degradação da lignina, por exemplo, ocorre por meio de fungos que produzem enzimas ligninolíticas extracelulares. O uso de enzimas é considerado na atualidade, um dos maiores setores da indústria biotecnológica. A exploração vem sendo feita da forma bruta, a partir de origem animal e vegetal, ou pelo aproveitamento da expressão enzimática decorrente do crescimento microbiano sobre determinados substratos (COLEN, 2006).

O sistema de degradação de materiais ligninocelulósicos envolve uma série de reações. As espécies de basidiomicetos, incluindo as do gênero Trametes, são capazes de realizarem a degradação, devido ao complexo enzimático ligninocelulolítico específico (ALVES, 2010). Dessas enzimas, as que estão em um maior nível de estudo são as Lignina peroxidases (LiPs), Manganês peroxidases (MnPs) e Lacases (Lacs) (GUILLÉN et al., 2000; CONESA et al., 2002; SIGOILLOT, 2012; JANUSZ G, 2013).

Desse modo, o presente trabalho propõe obter e caracterizar na forma recombinante a enzima Manganês peroxidase $(\mathrm{MnP})$ do fungo Trametes villosa, objetivando-se uma futura aplicação na deslignificação no bagaço de cana.

\section{METODOLOGIA}

A linhagem do fungo Trametes villosa foi adquirida na Coleção de Cultura de Microrganismos da Bahia (CCMB) da UEFS, com número de identificação CCMB561, preservado em método Castellani. Para a reativação do fungo e indução da enzima de interesse o micélio de T. villosa foi transferido para o meio de cultura sólido, Agar batata e dextrose (BDA) e posteriormente o micélio foi transferido para o meio de cultura sólido ABSA (Agar, bagaço de cana e sulfato de amônio) sendo incubado em B.O.D a $28^{\circ} \mathrm{C}$ por 7 dias. 
No procedimento de extração de RNA, seguiu-se o protocolo do Reagente Trizol (Invitrogen ${ }^{\circledR}$ ). Os materiais necessários foram: cadinho, pistilo, espátula, bisturi pinça e ponteiras estéreis. Os equipamentos necessários foram: centrífuga $5804 \mathrm{R}$ (eppendorf ${ }^{\circledR}$ ), vórtex MS1 Minishaker $\left(\right.$ IKA $^{\circledR}$ ), pipetas (eppendorf ${ }^{\circledR}$ ), NanoDrop200 (Termo Scinetific $^{\circledR}$ ), cuba de eletroforese, fotodocumentador (KODAK EDAS $290^{\circledR}$ ).

Para o processo de extração fez-se a remoção do fungo da placa de petri, transferindo-o para o cadinho e macerado em nitrogênio liquido, após o fungo ser totalmente macerado foi transferido para um microtubo (eppendorf ${ }^{\mathbb{B}}$ ) de $2 \mathrm{~mL}$, em seguida adicionou-se $1 \mathrm{~mL}$ do reagente Trizol (Invitrogen ${ }^{\circledR}$ ) e foi homogeneizado em vórtex por aproximadamente 5 segundos; após homogeneizado a mistura foi incubada em gelo por 5 minutos. Decorridos os cinco minutos fez-se o procedimento para a separação das fases, adicionou-se $200 \mu \mathrm{L}$ de clorofórmio e em seguida agitou-se manualmente por 15 segundos, depois foi incubado por 3 minutos em gelo, seguindo-se, foi centrifugado a $12.000 \mathrm{xg}$, por 10 minutos a $4^{\circ} \mathrm{C}$. Depois de centrifugada houve a formação de 3 fases, sendo estas: clorofórmio-fenol, interfase e a fase aquosa, esta foi transferida para um novo microtubo. Após a separação das fases, fez-se o isolamento do RNA; nesse processo adicionou-se $500 \mu \mathrm{L}$ de isopropanol $100 \%$ à fase aquosa e em seguida foi incubado em gelo por 10 minutos, após isso centrifugou-se a 12.000x $g$ por 10 minutos a $4^{\circ} \mathrm{C}$, prosseguindo-se, foi retirado o sobrenadante e o pellet foi lavado com $1 \mathrm{ml}$ de etanol $75 \%$, agitou-se em vórtex, em seguida centrifugou-se novamente a $7500 \mathrm{xg}$ por 5 minutos a $4^{\circ} \mathrm{C}$, descartou-se o sobrenadante e deixou-se o pellet secar por até 10 minutos. Transcorridos esse tempo o RNA foi ressuspendido em $50 \mu \mathrm{L}$ de água RNAse-free e utilizando se a pipeta foi feito movimentos up-down por até cinco vezes, o RNA obtido foi armazenado em $-20^{\circ} \mathrm{C}$. O RNA extraído foi analisado quantitativamente pela técnica de espectofotometria NanoDrop2000 (ThermoScientific $^{\circledR}$ ), no comprimento da onda A260/280nm e tendo como fator de correção 40, observando-se a razão 260/280nm e 260/230nm. Sendo também analisado por visualização em fotografia digital (KODAK EDAS 290 ${ }^{\circledR}$ ), após 1 hora de corrida eletroforética.

A síntese de DNA complementar (cDNA), foi feita em duas etapas, na etapa 1 foi feita a digestão das moléculas de DNA, com enzimas de DNAse I, o mix dessa reação foi preparado adicionando-se em um eppendorf estéril de $200 \mu \mathrm{L}, 8 \mu \mathrm{l}$ do RNA total extraído, $1 \mu \mathrm{L}$ da enzima DNAse I e $1 \mu \mathrm{L}$ do tampão DNAse I 10x, em seguida foi incubado por $30 \mathrm{~min}$, sendo $15 \mathrm{~min}$ à temperatura ambiente e $15 \mathrm{~min} \mathrm{a} 65^{\circ} \mathrm{C}$. Decorridos os 30 minutos procedeu-se a etapa 2, reação da transcriptase reversa, o mix dessa reação foi feito adicionando-se em um eppendorf estéril de $200 \mu \mathrm{L}, 5 \mu \mathrm{L}$ de RNA tratado com DNAse I, $1 \mu \mathrm{L}$ de dNTPs $10 \mathrm{mM}, 1 \mu \mathrm{L}$ de OligodT, $3 \mu \mathrm{L}$ de Água Nuclease free em seguida foi incubado a $65^{\circ} \mathrm{C}$ por 5 min e submetido a banho de gelo por 1 min. Prosseguindo-se foi adicionado $4 \mu \mathrm{L}$ de $\mathrm{MgCl}_{2} 25 \mathrm{mM}, 2 \mu \mathrm{L}$ de DTT 0,1 M, 2 $\mu \mathrm{L}$ de tampão RT 10x e $1 \mu \mathrm{L}$ da enzima inibidora RNAse out sendo incubada a $42^{\circ} \mathrm{C}$ por 2 min. Em seguida adicionou-se $1 \mu \mathrm{L}$ da enzima Super Script II RT, e novamente o mix foi incubado sendo a $42^{\circ}$ por $50 \mathrm{~min}$ e a reação foi parada a $70^{\circ}$ por 15 min e submetida a banho de gelo. No passo final foi adicionado $1 \mu \mathrm{L}$ da enzima RNAse $\mathrm{H}$, em seguida a reação foi incubada a $37^{\circ} \mathrm{C}$ por $20 \mathrm{~min}$, decorridos o tempo o cDNA sintetizado foi armazenado em um freezer à temperatura de $-20^{\circ} \mathrm{C}$.

O primer para o gene da enzima MnP foi desenhado a partir da sequência parcial nucleotídica obtida por Carneiro (2011). Para verificar a estrutura do primer, porcentagem de conteúdo $\mathrm{C} / \mathrm{G}$, bem como temperatura de melting $(\mathrm{Tm})$ foi utilizado o simulador gratuito de construção de primers disponível na página http://www.idtdna.com/analyzer/Applications/OligoAnalyzer/Default.aspx. 
Tabela 1.Dados referentes aos primers senso desenhados

\begin{tabular}{c|ccc}
\hline Denominação & Seqüência $\left(\mathbf{5}^{\prime} \mathbf{3}^{\prime}\right)$ & $\begin{array}{c}\text { Teor de } \\
\mathbf{C} / \mathbf{G}\end{array}$ & $\begin{array}{c}\text { Temp. de } \\
\text { melting }(\mathbf{T m})\end{array}$ \\
\hline MPerox_TvF & $g T T C C A C A C T C C C g A C C A g$ & $59,93 \%$ & $63^{\circ} \mathrm{C}$ \\
\hline
\end{tabular}

Para a amplificação do cDNA foi utilizada a estratégia de reação de polimerização em cadeia (PCR). Como fita molde foi utilizada a primeira fita de cDNA e, como iniciadores, o primer para o gene (como senso) e oligo-dT (Ancor Primer, antisenso). Para a reação de PCR foi utilizado o kit GoTaq® Green Master Mix: tampão de reação, dNTPmix $10 \mathrm{mM}$ (cada), iniciadores para o gene (senso e anti-senso), DNA molde (cDNA), enzima GoTaq polimerase $5 \mathrm{U} / \mu \mathrm{L}$, e água estéril, seguindo-se as instruções do fabricante. A reação de PCR foi feita seguindo-se os seguintes passos descritos na Tabela 2.

Tabela 2 - Dados referentes à reação de polimerase em cadeia

\begin{tabular}{c|ccc}
\hline Passo & Temperatura $\left({ }^{\circ} \mathbf{C}\right)$ & Tempo & Ciclos \\
\hline Desnat. Inicial & 95 & 3, & 1 \\
Desnaturação & 95 & $45^{\prime}$, & 35 \\
Anelamento & 55 & 1, & 35 \\
Extensão & 72 & 3, & 35 \\
Extensão Final & 72 & 5, & 1 \\
Final & 16 & - & 1 \\
\hline
\end{tabular}

\section{RESULTADOS E DISCUSSÃO}

Com o intuito de promover o desenvolvimento da biomassa micelial bem como a expressão da enzima Manganês peroxidase (MnP), o fungo Trametes villosa foi cultivado em meio BDA e em meio ABSA. O cultivo do fungo em BDA (Figura 1) por sete dias a partir dos resultados por analises quantitativa e qualitativa foi considerado aceitável em relação à produção de biomassa micelial, presumivelmente pelo fato do meio ser rico em nutrientes, não favorecendo assim a expressão da enzima de interesse pelo fungo T.villosa. No entanto, quando cultivado em meio ABSA (Figura 2) (ágar, bagaço-de-cana e sulfato de amônio), o fungo apresentou menor crescimento de biomassa, pelo fato do meio ser rico em substrato ligninocelulosico, sendo o resultado considerado satisfatório para a produção da enzima MnP pelo fungo T. villosa.
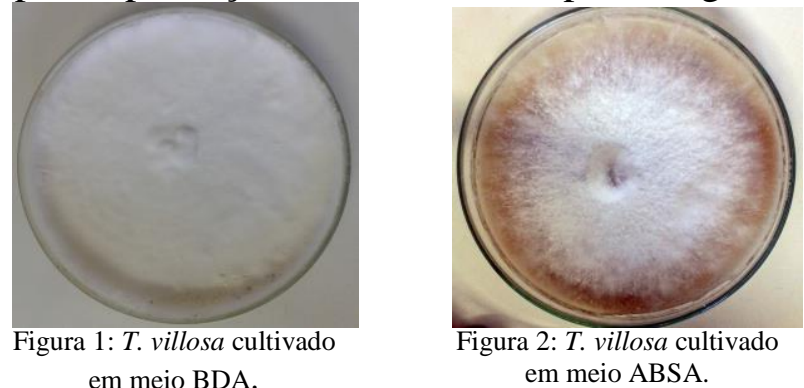

Segundo alguns autores, como Menezes, Silva \& Durrant (2009), Pirota et al., (2009) e Regina et al., (2009) o bagaço de cana é um substrato com potencial capacidade de induzir a produção de enzimas ligninolíticas, devido ao alto teor de lignina presente na sua estrutura. Por outro lado, o meio não favorece a grande produção de biomassa micelial por ser um meio pobre em nutrientes, corroborando Carneiro (2011). O micélio de T. villosa quando cultivado em meio ABSA, foi submetido à extração de RNA total, verificando-se a integridade do RNA extraído (Figura 3). 


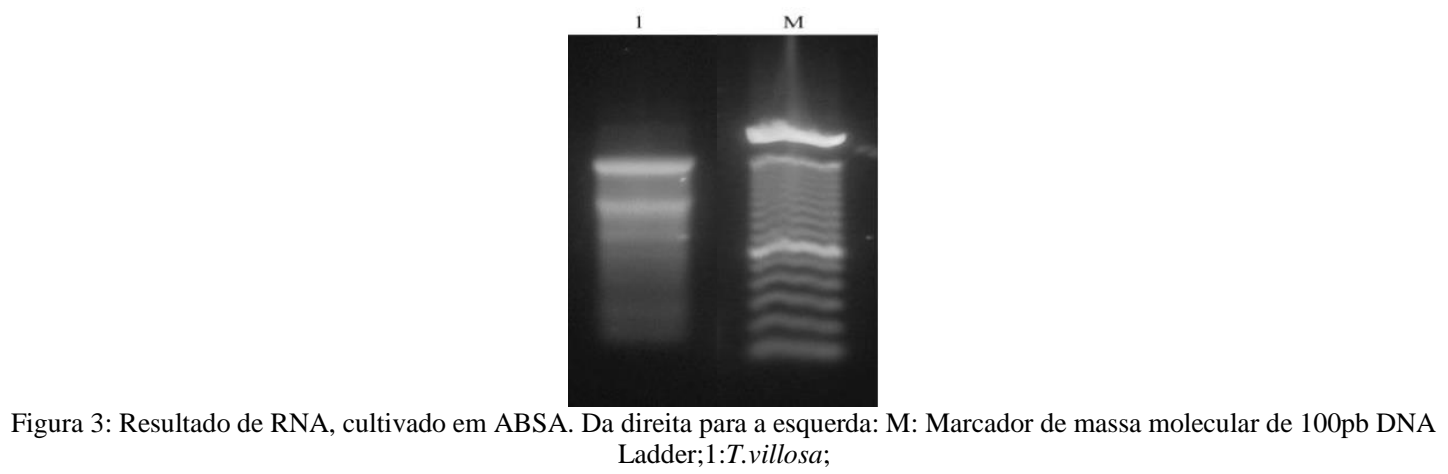

Em relação à amplificação da $\mathrm{MnP}$ por meio da técnica de $\mathrm{PCR}$, verificou-se o anelamento do primer formando um produto de aproximadamente $500 \mathrm{pb}$. A formação do fragmento de 500pb a partir do anelamento do primer na região de interesse comprova a indução da enzima MnP pelo fungo T. villosa sob as condições utilizadas.

O amplificado está em fase de clonagem para sequenciamento e início dos experimentos referentes à produção da enzima de forma recombinante.

\section{CONCLUSÃO}

A partir dos resultados por meio da extração de RNA, pode-se concluir que o meio ABSA foi o mais favorável para a expressão da enzima Manganês peroxidase pelo fungo T. villosa. Com base no produto de T. villosa, após a reação de PCR, foi possível verificar o fragmento de 500pb referente à amplificação da região específica de $\mathrm{MnP}$, confirmando que houve a indução da enzima Manganês peroxidase. Os estudos seguirão avançando para a produção da enzima na forma recombinante.

\section{REFERÊNCIAS}

ALVES, F. Modelagem e simulação de biorreator operando com fungos trametes versicolor para produção de enzima lacase. / Fabiano Alves - São Caetano do Sul, SP: CEUN-EEM, 2010. 80 p.

BALLESTEROS, M. 2001. Estado del desarrollo tecnológico del aprovechamiento de biomasa: Biocombustibles para el sector del transporte. Energía,161(1):29-34.

CARNEIRO, R.T.O. Produção das enzimas lignina e manganês peroxidases; isolamento e caracterização parcial do gene da LiP de uma linhagem de Trametesvillosa isolada do semi-árido brasileiro. 2011. Dissertação (Departamento de Ciências Biológicas). Universidade Estadual de Feira de Santana. 2011.

CARVALHO, M.E.A. Produção de Lignina Peroxidase e sua Aplicação no Biobranqueamento de Pasta de Celulose. 2003, 160 f. Tese (Doutorado em Ciências) Universidade Federal do Rio de Janeiro. Rio de Janeiro, 2003.

CASTRO, A.M., Pereira Jr., N., 2010. Produção, propriedades e aplicação de celulases na hidrólise de resíduos agroindustriais. Química Nova, 33, 1-12.

COLEN, G. Isolamento e seleção de fungos filamentosos produtores de lipases. Minas Gerais: UFMG, 2006. 206 p. Tese (Doutorado) - Programa de Pós- Graduação em Ciência de Alimentos, Faculdade de Farmácia da UFMG, 2006.

MENEZES, C. R.; SILVA, I. S.; DURRANT, L. R. Bagaço de cana: fonte de produção de enzimas lignocelulolíticas. Estudos tecnológicos vol. 5, nº1. p. 68-78, 2009.

REGINA, M.; BROETTO, F.; GIOVANNOZZI-SERMANNI, G.; MARABOTINI, R.; PERANNI, C.; LINDE, G. A. et al, Atividade de enzimas oxidativas do Lentinulaedodes em substratos agroindustriais Semina: Ciências Agrárias vol 30. nº 4, p. 881-888, Londrina, out./dez., 2009. 